\title{
Political Functions of Impunity in the War on Terror: \\ Evidence from Afghanistan
}

lavor Rangelov and Marika Theros

\section{Introduction}

The impact of the War on Terror on human rights has preoccupied the academic community since the attacks of September 11, 2001. Much of the discussion is framed by a set of tensions and trade-offs between security and human rights, which are not necessarily new but acquire new significance in the context of the global campaign to eradicate terrorism. Scholars have examined the human rights implications of specific security practices employed in the War on Terror, such as torture and targeted assassinations, and have probed broader anxieties about the compatibility of human rights commitments and public security considerations in a post9/11 world (Gearty 2006; Ignatieff 2004; Watkin 2005).

The issue of impunity for gross human rights abuses in the War on Terror has attracted significant attention. Some studies examine the strategies used by governments to undermine accountability norms and structures under the banner of fighting terrorism, such as the Bush Administration's campaign against the International Criminal Court (ICC) and other attempts to subvert international law (Chinkin and Kaldor 2017; Bartholomew 2006; Galbraith 2003). Others show how even when serious abuses are publicly exposed the implicated individuals and institutions are rarely held to account (McCoy 2012), prompting claims that the War on Terror is 
reconfiguring power in Western democracies by giving rise to 'sovereign impunity' (Welch 2009). Less attention, however, has been paid to the ways in which impunity itself might be shaping some of the security objectives and practices of the War on Terror and enabling or constraining their pursuit.

In this paper, we draw on security cultures theory and analysis of empirical evidence from Afghanistan to demonstrate that there is a certain logic to the prevalence and persistence of impunity in the War on Terror. That logic has to do with the role of impunity in generating the kind of politics that provides a justification for an endless war and enables the pursuit of its shifting goals and methods. We treat the War on Terror as a security culture - a combination of security objectives and security practices tied to a particular form of political authority (Kaldor 2016, 2018) - and argue that impunity works as a mechanism for reproduction and diffusion of that culture and for co-option and subversion of another security culture, the Liberal Peace. The argument is elaborated by investigating the political functions of impunity in the War on Terror, which include the construction of an enemy, creation of a favorable environment for prosecuting the war, and capture of peacebuilding and statebuilding interventions.

What is meant by impunity in this context? The updated Set of Principles for the Protection and Promotion of Human Rights through Action to Combat Impunity defines impunity as "the impossibility, de jure or de facto, of bringing the perpetrators of violations to account whether in criminal, civil, administrative or disciplinary proceedings - since they are not subject to any inquiry that might lead to their being accused, arrested, tried and, if found guilty, sentenced to appropriate penalties, and to making reparations to their victims" (UN Economic and Social Council 2005: 6). We find this definition useful because it emphasizes the 
impossibility of holding perpetrators to account, rather than simply a failure to do so. But we adapt it to the complexities of a war zone that has served as a major battleground in the War on Terror by delineating its scope in several ways, suggesting that impunity should be understood as a continuum or spectrum in that context.

By drawing on insights from security cultures theory, the paper provides a novel perspective on discussions of human rights in the War on Terror and highlights the potential of security studies to illuminate salient human rights issues in that context. We suggest that the concept of 'security cultures' is a useful analytical tool for explaining divergent human rights outcomes in different types of security interventions such as counterterrorism and peacebuilding. The paper contributes to the emerging literature on security cultures in two ways. Firstly, our analysis advances understanding of the mechanisms through which the War on Terror is (re)produced as a security culture and draws attention to their implications for understanding pathways in the security field. Secondly, the paper brings out the extent and significance of the interactions between security cultures and shows how core components of one security culture may be hijacked by another, dominant culture in a particular context.

The Afghan case is particularly useful for investigating these issues empirically because Afghanistan was the first front in the War on Terror, serving as a laboratory for developing its goals, tactics and methods. The experience in Afghanistan (and Iraq) has generated deep tensions between objectives and practices, prompting continuous adaptation and realignment that help explain the pathway of the War on Terror since 9/11. In that period Afghanistan has also been a site of major peacebuilding and statebuilding efforts, the sort of multilateral interventions associated with the security culture of the Liberal Peace and its central 
preoccupation with stability, thus affording opportunities to examine how the War on Terror and the Liberal Peace interact, coexist and compete in a security environment where both are salient.

The next section discusses the logic and characteristics of the War on Terror as a security culture and considers how existing scholarship has approached the question of impunity in that context. The following section briefly examines the spectrum of impunity in Afghanistan. The final section identifies and analyzes a set of political functions of impunity in the War on Terror, drawing primarily on the Afghan case, and the conclusion draws out the main implications of the findings.

\section{Impunity and the Security Culture of the War on Terror}

There is a substantial theoretical literature that is helpful in investigating the logic of the War on Terror as a security culture and illuminating the ways in which that logic might generate and/or depend on impunity. Before reviewing the literature, however, it is important to clarify what we mean by 'security cultures' and why the concept adds value analytically.

Security culture theory starts from the premise that security policy is undergoing a profound transition since the end of the Cold War but there is no clear direction that can be identified. Instead, a plethora of security ideas, norms and practices coexist and compete. The concept of 'global security cultures' aims to provide a theoretical framework for making sense of this transitional moment by identifying and analyzing pathways in the security field.

A global security culture is defined as a combination of objectives (norms and ideas about security) and practices (tools, rules, tactics, finance etc.) that are mutually constitutive 
but also imperfectly aligned, and tied to a specific form of political authority (Kaldor 2018, 2016). It differs from the concept of 'strategic culture' (Gray 1999) in that the terms 'culture' and 'global' are used to denote different ways of doing security that are embedded in a set of social relations and meanings rather than in national identity or territory: "The point is that the inhabitants of each culture have more in common, possibly even needing the existence of each other to reproduce themselves, than the inhabitants of different cultures even though they may share the same territorial space" (Kaldor 2018: 21). For example, intelligence agencies and security contractors inhabiting the War on Terror culture share certain enemy-centric meanings and interpretations of the Afghan conflict and its solutions, whether they might be in Washington or Kabul, which differentiate them from the humanitarian and development workers who inhabit the Liberal Peace culture. And these interpretations might be completely at odds with how most Afghans interpret and experience the conflict.

Security cultures are socially constructed and dynamic, they have to be continuously reproduced by refining and realigning objectives and practices and in that process they may become more resistant or more open to change. A settled typology of security cultures is yet to emerge but Geopolitics, the Liberal Peace, New Wars, and the War on Terror have been discussed in this vein in the literature (Kaldor 2018; Chinkin et al. 2016; Rangelov 2016). These are treated as ideal types rather than empirical categories and their boundaries are blurred. Nevertheless, different security cultures exhibit distinctive internal logics that can be analyzed by studying the mechanisms through which they are reproduced and the degree to which objectives and practices are aligned with or contradict each other. The analytical value of the theoretical framework is in enabling investigation of security pathways by understanding and 
interpreting the logics of security cultures and helping to identify openings and closings for change associated with the specific methods of their reproduction. The framework is useful in this enquiry because it calls for analysis of the ways in which impunity might enable or constrain the objectives and practices of the War on Terror, thereby shaping its reproduction and evolution over time.

Existing research that examines the logic and characteristics of the War on Terror often uses the work of Carl Schmitt as a foil, drawing in particular on his concept of the political and the exception. Schmitt argues that politics is the domain of human association and rests on a 'friend-enemy' distinction, an extreme and intense antagonism that has to involve "the real possibility of killing" (Schmitt 1996: 33). His understanding of politics is rooted in a forceful critique of liberalism, which he accuses of substituting perpetual discussion for the political and turning the enemy into a debating adversary. The problem with liberal constitutional frameworks of pre-existing rules and procedures is their inability to answer the ever-present possibility of crisis, to anticipate the emergency: "The exception is that which cannot be subsumed, it defies general codification, but it simultaneously reveals a specifically juristic element - the decision in absolute purity" (Schmitt 1985: 13). Sovereign power is manifested precisely in the state of exception, captured in Schmitt's famous dictum that sovereign is he who decides on the exception. The constitution and rule of law may be suspended by sovereign decision if deemed necessary to eliminate the emergency. This argument represents an attack on the entire tradition of the rule of law ideal, which has been chiefly concerned with restraining sovereign power (Tamanaha 2004). Schmitt's answer is that all law is situational but life is unruly: "In the exception the power of real life breaks through the crust of a mechanism 
that has become torpid by repetition" (Schmitt 1985: 27). Law matters but ultimately, human affairs depend on humans and the rule of law gives way to the rule of man.

It has been argued that at the heart of the security culture of the War on Terror is the notion of a permanent state of exception, a permanent war that requires permanent mobilization against an enemy (Kaldor 2018). The logic of a permanent state of exception is embedded in a set of distinctive objectives and practices. The War on Terror is fought against individuals rather than states, a war of the manhunt (Chamayou 2011) conducted at home and abroad in ways that blur the boundaries between the inside and the outside and give rise to an opaque complex involving intelligence and surveillance assemblages, cyberattacks, the growing use of drones, private contractors and special forces, and the normalization of practices such as indefinite detention and targeted assassinations (Kaldor 2018). By mobilizing against an elusive enemy in a permanent state of exception, and relying on tactics and methods shrouded in secrecy to fight it, the security culture of the War on Terror presents formidable challenges for established legal frameworks and accountability mechanisms. A 'pattern of impunity' emerges in that context whereby "demonization of a particular enemy creates space for abuses by those who claim to be fighting this pariah" (Keen 2006: 65).

Another central concern in the literature is about the logic of power in the War on Terror, revealed in the character of political authority constructed in the war. Some theorists suggest that the state of exception can be seen as a working paradigm of government in the West, whereby political decisions are based on emergency powers and made outside the law. The War on Terror marks the global extension of that paradigm: "The normative aspect of law can thus be obliterated and contradicted with impunity by a government violence that - while 
ignoring international law externally and producing a permanent state of exception internally nevertheless still claims to be applying the law" (Agamben 2005: 87). The production of a permanent state of emergency is interpreted as an essential practice of states engaged in the War on Terror and impunity becomes central to the logic of power that creates a 'judicial void' in which to operate.

Other scholars detect a distinctive logic of power in practices such as indefinite detention of 'unlawful combatants' and the use of military tribunals by the Unites States after 9/11 (Butler 2004). State power is reconfigured by the coming together of Schmittean sovereignty and Foucauldian governmentality - that mode of power concerned with the management and regulation of populations (see Foucault 1991). The suspension of the rule of law is understood both as an act of sovereign power and a tactic of governmentality. It produces a sort of lawless or 'rogue' power exercised by executive and managerial officials outside established accountability structures. In deciding who should be detained and for how long, for example, such 'petty sovereigns' find themselves "delegated with the power to render unilateral decisions, accountable to no law and without any legitimate authority" (Butler 2004: $56)$.

Criminologists draw attention to some of the ways in which power may also be reconfigured by using the law. They reveal a set of practices employed in the fight against terrorism that are based on a precautionary logic and take the form of counter-law: "New laws are enacted and new uses of existing laws are invented to erode or eliminate traditional principles, standards, and procedures of criminal law that get in the way of pre-empting imagined sources of harm" (Ericson 2007: 24). These 'laws against law' work by identifying 
suitable enemies and criminalizing them for imagined future harm rather than past offenses. The surveillance assemblages through which they are enforced further enhance the 'rogue' power of the executive branch by giving it unchecked authority to criminalize. Scholars have interpreted such developments as evidence for the rise of a political economy of impunity in the War on Terror, which involves the extension of 'sovereign impunity' to public actors but also the growth of private contractors who perform critical intelligence, surveillance, and warfighting functions and who are also shielded from accountability for abuses (Newburn 2007; Welch 2009) or subjected to abuse themselves (Coburn 2018).

In sum, existing research suggests that impunity is central to the logic of the War on Terror as a security culture and demonstrates how it is produced by a set of ideas and practices in which that logic is embedded, emphasizing in particular how impunity becomes a defining feature of the specific kind of political authority constructed in the war. The rest of the paper builds on these insights but takes the literature a step further by investigating the role of impunity in the reproduction and diffusion of the security culture of the War on Terror and the co-option and subversion of the Liberal Peace, drawing mainly on empirical evidence from Afghanistan.

\section{Afghanistan: A Spectrum of Abuse with Impunity}

Abuse of power taking different forms - human rights violations, political marginalization, corruption - has become so widespread and entrenched in Afghanistan that for some observers it represents an organizing principle of the post-Taliban order and a driver of persistent conflict (Carter and Clark 2010; Ladbury 2009; Rangelov and Theros 2012). The issue of impunity for 
human rights violations in the War on Terror has to be approached in that broader context, whereby the impossibility of holding perpetrators to account is understood as a continuum or spectrum. The impunity spectrum has three characteristics that are particularly important for this enquiry.

First, impunity for past human rights violations underpins and perpetuates impunity for ongoing violations and the other way round. By the time the War on Terror was launched with the U.S.-led military intervention in Afghanistan, the country had already been caught in intractable conflict for more than two decades. The cycles of violence were set in motion by the Communist coup and Soviet invasion (1978-1979) and continued during the years of Sovietbacked rule and civil war (1979-1996) and Taliban rule (1996-2001). War crimes and gross human rights violations were committed in every phase of the conflict, including torture, summary executions and indiscriminate bombing of the countryside during the Communist period and ethnic cleansing, sexual violence, and shelling of civilian areas in Kabul during the civil war (Rubin 2003). While the gravity of these abuses and the ways in which Afghan communities remember and interpret them may differ, the rise of the Taliban was partly a response to such brutalities and the prevailing culture of impunity that was seen as fueling them. The Taliban also consolidated and maintained power by engaging in severe forms of abuse and repression, targeting in particular political enemies, women and ethnic minorities.

The fall of the Taliban did not disrupt the pattern of impunity for Afghanistan's historical legacies of abuse. Instead, it paved the way for the incorporation of many known perpetrators in power structures at the central, provincial and district level, effectively making impossible their prosecution and punishment either for past human rights violations or for ongoing abuses. 
Former civil war commanders associated with the Northern Alliance and implicated in mass atrocities became the main beneficiaries of the C.I.A.-led counterterror campaign (Woodward 2002). Their role as key allies in the War on Terror has helped to shield them from accountability even for widely publicized atrocities, such as the massacre of prisoners in Dashte-Laili in 2001 (Herman and Peterson 2010). Supported and protected by powerful patrons, many warlords consolidated power by employing brutal tactics that became "one of the most serious threats to security for most Afghans" (Grossman 2009: 9). The growth of the insurgency over time has reinforced U.S. reliance on local partners, especially in the southern and eastern provinces, giving rise to a new generation of strongmen and militias exempted from accountability for abuses.

Secondly, all major types of actors involved in the War on Terror and the provision of governance and security in the country - public and private, international and local, military and civilian - are effectively shielded from accountability for human rights violations and other serious abuses. This includes members of the Afghan National Security Forces, ministers, governors, and other agents of the nascent Afghan state (Ruttig 2013; Human Rights Watch 2015; Felbab-Brown 2016). It also includes international military forces and private security contractors in a war that has relied on methods and tactics like indefinite detention, coercive interrogation techniques, heavy-handed night raids, targeted assassinations and airstrikes causing civilian casualties.

Even though U.S. and NATO forces and private contractors have come under pressure to reign in some of the most abusive practices, perpetrators of specific violations have rarely been prosecuted and punished. Investigations are usually launched only after a major public outcry 
and media pressure. Convictions are extremely rare and tend to involve direct perpetrators rather than command responsibility, feeding a narrative of 'a few bad apples'. At the time of writing, the space for accountability is further narrowed by the Trump Administration's forceful attack on the ICC. The ICC investigation in Afghanistan covers war crimes committed by proand anti-government forces since 2003, including U.S. military personnel and members of the C.I.A. If the investigation moves forward, the U.S. government threatens to 'fight back' by imposing sanctions on the ICC and its staff and initiating criminal proceedings against judges and prosecutors.

Finally, there is a dynamic relationship between impunity for atrocity crimes and for economic crimes that has to do with the predatory character of the political and economic order that emerged in Afghanistan during the War on Terror. Networks of public and private actors responsible for some of the most serious human rights abuses are also the ones that often benefit the most from the political economy of counterterrorism and statebuilding (Felbab-Brown 2017; Rangelov and Theros 2012). These networks drive processes of state capture and criminalization and have become adept at harnessing their links to the highest echelons of power to subvert accountability processes and mechanisms. When local lawenforcement officials with international support try to investigate and arrest high-level perpetrators, for example, they are often intimidated, blocked, dismissed or even arrested (Author Interviews, Kabul, 2011; SIGAR 2016). Some observers describe the prevailing configuration of power as a 'criminalized peace' (Goodhand 2008; Maass 2011), whereby large amounts of foreign security assistance purchased the loyalty of elites allied in the War on Terror 
while fueling criminality and impunity across Afghanistan's political, economic and security landscape.

\section{Political Functions of Impunity in the War on Terror}

The spectrum of impunity in Afghanistan has to be understood in relation to the War on Terror as a dominant security culture and its interactions with another security culture present in that environment, the Liberal Peace. Through analysis of the specific ways in which impunity has enabled or constrained the pursuit of key objectives and practices of the War on Terror in the Afghan case, we demonstrate that impunity works as a mechanism for reproduction of the War on Terror and capture for its purposes of key components of the Liberal Peace. We identify three functions of impunity that are particularly significant in that respect, which have to do with the role of impunity in generating the politics that provide a justification for the war, create favorable conditions for its conduct, and facilitate processes of co-option and subversion of peacebuilding and statebuilding by the War on Terror.

\section{Constructing an Enemy}

The logic of the security culture of the War on Terror as a permanent mobilization against an enemy depends on the ability of political authority to construct an enemy that can be plausibly presented as an existential threat that requires a military response, and to continually reproduce that construct. The evidence from Afghanistan suggests that impunity plays a critical role in making that possible. One function of impunity involves its role in generating the friendenemy antithesis that underpins the politics of the War on Terror and constructing the sort of 
permanent enemy that helps to substantiate dominant narratives and justifications for endless war.

The War on Terror was launched with the decision of the Bush administration to interpret the attacks of $9 / 11$ as an act of war and to respond with a military intervention in Afghanistan. The alternative to the 'war' model pursued by the United States was a 'justice' model that entailed interpreting the attacks as crimes against humanity and treating their perpetrators not as political enemies who must be defeated but rather as criminals who should be apprehended, prosecuted and punished (Wilson 2005), i.e. adopting a law-enforcement approach. Discarding that alternative in favor of war represented a sovereign decision, an exercise of sovereign power in a state of emergency, and its justification required a political enemy in the Schmittean sense.

The existence of that kind of enemy was not immediately apparent, however. In the aftermath of 9/11, the Taliban made several offers to apprehend Osama Bin Laden and eliminate the presence of Al Qaeda in the country. That option was dismissed by an administration already preoccupied with mobilizing for war and constructing a formidable enemy that could justify military intervention and regime change in Afghanistan. ${ }^{\text {ii }}$ Rhetorically, the strategy centered on collapsing the distinction between the Taliban and Al Qaeda, recasting the former in the image of the latter and framing them as an existential threat to the security of the United States and its allies. Thus President Bush argued that "the Taliban and Al Qaeda are one and the same," describing them as "barbaric criminals" who "burrow deeper into caves and other entrenched hiding places" and must be "hunted down" by American forces (Bush 2001, paras $6 \& 9$ ). Scholars have contested the validity of conflating the Taliban and Al Qaeda and 
have drawn attention to the role of that 'myth' in creating a monolithic enemy in Afghanistan (Strick van Linschoten and Kuehn 2012).

Rhetorical strategies alone, however, cannot justify and sustain the sort of permanent mobilization against an enemy that is central to the politics of the War on Terror. The rhetoric has to be substantiated in more concrete, tangible ways. One approach was to produce intelligence that could feed the war effort and corroborate the claims of the administration about the character and magnitude of the terrorist threat. Impunity played an important role in operationalizing that approach at the sharp end, which involved coercive interrogation of inmates in places like Bagram Air Base in Afghanistan and Abu Ghraib in Iraq. The Detention and Interrogation Program of the C.I.A. was authorized covertly by President Bush in September 2001 and terminated with an executive order of President Obama in January 2009, although there are indications that President Trump might try to revive certain elements of the program (Savage 2017). Some of the detainees were captured in combat operations while others were forcibly disappeared or 'rendered'. Many were interrogated with 'enhanced' techniques such as sleep deprivation and nudity, wallings (slamming detainees against a wall) and waterboarding. A program that routinely employed such brutal methods could only run if C.I.A. operatives and contractors were shielded from accountability for human rights abuses. Although many details of the program remain shrouded in secrecy, declassified assessment of its implementation conveys a culture of impunity tolerated, if not encouraged, by senior C.I.A. leadership. ${ }^{\text {iii }}$

Another way in which impunity has contributed to the construction of an enemy in Afghanistan has to do with its role in the rise and growth of the insurgency. The crucial factor was the decision of the Bush administration to prosecute the War on Terror by forging strategic 
partnerships with commanders and militias associated with the Northern Alliance. Some of them became allies in the war effort simply because of their anti-Taliban credentials, 'the enemy of my enemy'; others were old friends and beneficiaries of the C.I.A. from the anti-Soviet struggle. Many among them, however, had also been implicated in atrocity crimes from the civil war period, including Northern Alliance leader Marshal Fahim and extremists like Abdul Rasul Sayyaf. The strategy hinged on ensuring that U.S.-backed warlords and strongmen enjoyed impunity for past human rights violations as well as for abuses that forces under their command were committing in the campaign to defeat the Taliban and Al Qaeda. That strategy proved to be more effective in creating an enemy than in eliminating one. The Taliban had largely disbanded and dispersed following the U.S.-led military intervention that removed them from power. In many cases, it was the brutality with which they were hunted down that provoked a backlash, generating enmity and pushing many of them into Pakistan, from where they subsequently mounted an insurgency.

The case of Kandahar is instructive. After the fall of Kandahar in early 2002, most Taliban - from the senior leadership down to the rank-and-file - effectively abandoned the movement, accepted the transitional government and returned to their homes. Sustained harassment and persecution, however, eventually prompted many to flee to Pakistan. Former Taliban officials who had been tortured in secret prisons run by factional commanders with ties to U.S. Special Forces, for example, subsequently re-emerged as key figures in the insurgency (Gopal 2010). Another important factor in Kandahar was dissatisfaction with the rise and growing dominance of an 'exclusive oligarchy' tied to the Karzai family and the international 
coalition (Forsberg 2010). Predatory rule and widespread abuse by corrupt officials and U.S.backed strongmen would then provide a groundswell of grievances from which to recruit. ${ }^{\text {iv }}$

\section{Creating an Enabling Environment}

The reproduction of the security culture of the War on Terror is a dynamic process that involves continuous refinement and realignment of objectives and practices as tensions and contradictions between them emerge and deepen. In Afghanistan the goal of defeating a constantly evolving enemy - terrorist groups including Al Qaeda and Islamic State and an increasingly heterogeneous insurgency comprising the Taliban, the Haqqani network and a number of smaller factions - has been pursued by employing a changing set of counterterrorism and counterinsurgency doctrines, capabilities and tactics. ${ }^{v}$ Impunity serves an important function in that process by helping to create an enabling environment for prosecuting the war and pursuing its shifting goals and methods.

Shielding perpetrators of atrocity crimes from accountability was particularly useful in securing a favorable political dispensation in Afghanistan at the onset of the War on Terror. Maintaining that kind of political dispensation over the years has depended on a combination of de facto and de jure amnesties. Impunity for war crimes and crimes against humanity effectively served to underwrite the political and economic influence of U.S.-backed warlords and strongmen and ensured their emergence as the new powerbrokers. By 2001, they had been all but wiped out by the Taliban. They had limited financial resources, controlled a sliver of territory and were generally unpopular among the population (Giustozzi 2009: 88-89). Their ability to gain de facto immunity from prosecution in exchange for contributions to the War on 
Terror paved the way for their political revival. In the newly constituted government, allied warlords were able to take control of key ministries such as Interior, Defense and the National Directorate of Security.

The political pay-offs of impunity have been instrumental in consolidating the power and influence of allies in the War on Terror and marginalizing political opponents. At key moments in the post-Taliban transition, the space for accountability was repeatedly narrowed at the behest of perpetrators of human rights violations because they were seen as indispensable partners in the war. At the Emergency and Constitutional Loya Jirgas, for example, rules barring candidates with poor human rights records from participating were circumvented by UN officials, allegedly under pressure from the Unites States, and commanders were able to attend as 'unelected guests' (Rashid 2009: 140) and consolidate their positions. Their growing influence was important in shaping the balance of power between competing factions in the government. Over time, President Karzai abandoned his efforts to sideline the commanders and started shedding some of the reformers in his government.

Advocates of accountability in Afghanistan, including the Afghanistan Independent Human Rights Commission (AIHRC) and civil society groups, have also been vocal critics of War on Terror practices such as arbitrary detention and airstrikes causing civilian casualties, repeatedly exposing abuses and demanding accountability. Marginalizing such actors politically has the added benefit of suppressing dissent about the conduct of the war. U.S.-backed commanders became adept at framing any calls for accountability as an attack on jihad and Islam in their rhetoric and pushing back by raising the specter of violence. That strategy was employed in 2005, when the adoption of the Action Plan for Peace, Justice and Reconciliation by 
the Afghan government coincided with the publication of a Human Rights Watch report on alleged perpetrators of atrocity crimes in positions of power (AIHRC 2005; Human Rights Watch 2005). Commanders mobilized around twenty thousand supporters for a rally in Kabul, many of them armed, to celebrate their role as jihadists against the Soviets and to send a message that accountability would be resisted by all necessary means, including the use of force.

The incident managed to suppress dissent not only in the human rights community but also among clerics and mullahs who were sympathetic to justice as an Islamic value, and was seen as "direct intimidation" by victims (Nadery 2007: 177). It paved the way for the adoption of an amnesty bill, thus giving a legal sanction to the state of de facto impunity in Afghanistan. The amnesty legislation furthered the objectives of the War on Terror in two ways. First, it protected partners in the war effort by closing the space for accountability for past human rights violations. Second, it was intended to encourage insurgent defection by providing immunity from prosecution for future offenses, as long as their perpetrators were prepared to accept the authority of the government and the constitution.

A more complex picture emerges from our analysis of the contradictions that impunity generates in the War on Terror, how such contradictions lead to adaptation and realignment of objectives and practices and how that might open up or close down space for alternative approaches. The Afghan case demonstrates how impunity can get out of hand and become a constraining factor in the fight against terrorism, complicating the war effort and creating divisions in the coalition. Rampant impunity for human rights abuses has enabled local allies to use increasingly violent strategies for consolidating power and removing opponents, thereby creating distinctive challenges for the War on Terror. One example is the ability of the 
insurgency to make inroads in formerly stable areas in the north by exploiting the dynamics of exclusion and marginalization. Consider the case of northern Afghanistan's most powerful strongman, Atta Mohammad Noor, who led the Jamiat forces against the Taliban in 2001 and became the "strongman governor" of Balkh province (Mukhopadhyay 2014: 76-65). A leaked NATO security report from 2014 describes how Atta maintained a grip on power in the face of growing opposition:

Many officials with influence in [the west of Mazar-e-Sharif], like most officials in Balkh province, have been closely tied to Gov. Atta, especially individuals within the ANSF [Afghan National Security Forces]. These people have been utilized to achieve and defend Gov. Atta's interests and personal aims in the area. Political influence has probably been consolidated by destabilizing the area in the [2009] elections. Also by using his patronage network to assassinate and harass political opponents, Atta has attempted to further strengthen his political position. Moreover, the relationship with criminals, especially drug traffickers, has likely been profitable and contributed to Gov. Atta's financial resources (quoted in Human Rights Watch 2015: 39).

In dealing with strongmen like Atta, who at some point become a liability, the preferred approach usually involves demotion or removal rather than accountability. When President Ghani tried to remove Atta from his post of governor in late 2017, he pushed back and refused to leave. A prolonged standoff between the two ended only after substantial external pressure was exerted and an agreement was reached to appoint Atta's preferred choices for governor 
and police chief. The standoff raised Atta's national profile, making him a credible rival to Ghani in the next presidential elections. Another example is Sher Mohammed Akhundzada in Helmand, whose militias inflamed the local population and helped the Taliban gain a foothold (Chandrasekaran 2012). After a U.S. raid on his compound found vast amounts of drugs and the British insisted on his removal before they deployed to Helmand, Karzai appointed him to the Senate and agreed to make his nephew a deputy governor. In other words, in some cases the contradictions engendered by impunity may prompt a degree of adaptation without creating any real openings for alternatives approaches.

In other cases, however, they may create genuine openings. Treating impunity as a spectrum that includes economic crimes is useful in examining how certain tensions and contradictions have spurred significant adaptation of goals and methods in the U.S.-led coalition. Corruption and organized crime have presented a growing challenge for advancing the main objective of defeating the enemy in Afghanistan and over time, shifting assessments of that challenge have generated a range of innovative responses.

In the early years of the intervention, efforts to reign in corruption were stymied by limited political will, an overemphasis on technical approaches, and lack of a shared understanding of the underlying problem. By 2009, however, corruption was increasingly seen as a strategic threat by U.S. and NATO officials as even their own research revealed how corruption strengthened illicit networks involving Afghan officials, criminals and insurgents, and contributed to insurgent financing and recruitment (Tierney 2010; Zyck 2012; SIGAR 2016). In response, several new instruments were created such as NATO's Task Force Shafafiyat, Task Force 2010, and the Major Crimes Task Force (MCTF) of the Afghan government, intended to 
tackle corrupt networks, prevent reconstruction and security assistance from reaching the enemy, and build state capacity to investigate and prosecute high-level corrupt officials. These efforts, however, were largely frustrated as a result of growing obstruction by the Karzai administration and, crucially, the pursuit of competing priorities and agendas by different U.S. agencies.

The ensuing power struggles revealed the impossibility of resolving fundamental contradictions between combating corruption, which implicated key allies in the War on Terror, and prosecuting a war that depended on their active support. They also exposed deep divisions in the war coalition and key actors working at cross-purposes. Consider, for example, the arrest and swift release of Mohammad Zia Salehi, an aide to President Karzai, in 2010. He was arrested in a joint operation of U.S. law-enforcement personnel and the MCTF on charges of soliciting bribes in exchange for obstructing an important investigation into a drugs network. Within hours of the arrest, President Karzai ordered Salehi's release and moved to restrict the work of Afghan anti-corruption units. A New York Times investigation revealed that while U.S. law-enforcement agents were working on his case, Salehi had remained on the payroll of the C.I.A. as an informant and collaborator (Filkins and Mazzetti 2010). As one analyst put it, "One part of U.S. policy corrupted Afghan officials while other parts tried to investigate and root out corruption. Given the interests that define the mission, concerns about corruption did not trump those of covert action" (Rubin 2015). The reproduction of the security culture of the War on Terror, in other words, is shaped both by the role of impunity in creating an enabling environment for the war, and by the frustrated efforts to introduce a measure of accountability in that environment. 
Co-opting and Subverting the Liberal Peace

Security cultures are global patterns of doing security defined by the shared ideas and practices of their inhabitants, which are embedded in a set of social relations and meanings rather than in political and cultural units such as nation-states (Kaldor 2018). Studying security cultures in any particular geography has to take into account how the components and inhabitants of different cultures present in that environment interact with each other, and to consider the potential significance of such interactions for explaining specific outcomes or pathways. In complex security environments such as war zones, multiple cultures and subcultures can be identified and analyzed along those lines. Nevertheless, it is usually possible to detect a dominant culture that interacts with other cultures by co-opting or subverting some of their components in ways that contribute to its own reproduction and diffusion.

Since 9/11, the security cultures of the War on Terror and the Liberal Peace have coexisted and interacted in Afghanistan as the war effort became enmeshed with some of the most ambitious peacebuilding and statebuilding operations attempted by the international community. ${ }^{\text {vi }}$ The Liberal Peace culture is distinguished from the War on Terror by its objectives - security is achieved by promoting stability at different levels rather than by defeating an enemy - and its practices, which are associated with the dramatic increase in multilateral interventions since the end of the Cold War and include peacemaking, peacekeeping, reconstruction and statebuilding efforts (Kaldor 2016). The relationship between the two cultures is complex and dynamic but our analysis of their interactions in Afghanistan suggests that a pattern can be discerned, whereby the emergence and diffusion of the War on Terror as a 
dominant security culture involves a process of capturing certain components of the Liberal Peace. Impunity plays an important role in structuring these interactions and shaping their outcomes, serving as a mechanism through which peacebuilding and statebuilding interventions can be repurposed and redeployed in the War on Terror.

Peace agreements are considered a central component of the Liberal Peace, providing the basis for international engagement in conflicts and regulating the cessation of hostilities, disaggregation of power, and international supervision (Bell 2008; Kaldor 2016). Some agreements include specific provisions for addressing impunity for atrocity crimes, for example the Dayton Accords provisions for cooperation with the International Criminal Tribunal for the Former Yugoslavia and the transitional justice provisions of the Colombian peace agreement. There are tensions in such agreements between accountability and the disaggregation of power, which usually takes the form of power sharing and may involve incorporation of perpetrators in power structures. Agreements without specific accountability provisions should not foreclose the possibility of pursuing justice and accountability at least in theory. The UN, for example, cannot endorse settlements that provide blanket amnesties for war crimes, crimes against humanity and genocide. Nevertheless, the main purpose of peace agreements is to end conflicts and prevent them from recurring, reflecting the core preoccupation with stability in the security culture of the Liberal Peace. To the extent that agreements may tolerate or engender a state of de facto impunity, the function of impunity is to facilitate the emergence of peace.

Impunity served a very different function in the peace agreement for Afghanistan concluded in December 2001 in Bonn. The political pay-offs of impunity were critical for hijacking the Bonn conference, undercutting the efforts of the UN team to negotiate something 
that resembled a peace settlement, and turning the Bonn Agreement into a sort of 'war pact' for prosecuting the War on Terror. As is often the case in peace talks, actors implicated in serious human rights violations participated in the discussions. But instead of bringing together the warring parties, the Bonn conference involved only one side. The talks included representatives of the major military factions allied with the U.S.-led collation in the War on Terror but excluded the Taliban. Other groups in Afghan society with stakes in the peace process, such as women and civil society, were also excluded.

Accountability for atrocity crimes became a sticking point at the negotiations. The UN draft agreement included provisions for implementing a process of disarmament, demobilization and reintegration (DDR) and for precluding amnesties for war crimes and crimes against humanity. These provisions caused a 'furor' in the negotiations, prompting some delegates to mobilize opposition to the agreement (Rubin 2003: 571-572) and were eventually removed. Instead, the final text of the agreement provides for integration of militias in the new armed forces and praises the mujahedeen for their past sacrifices and their future role as "champions of peace, stability and reconstruction of their beloved homeland" (UN Security Council 2001: Preamble). The Bonn Agreement helped to consolidate the political and military resources required for the War on Terror. Impunity could be interpreted as a price that had to be paid at Bonn, however not for peace.

Statebuilding is the other major component of the Liberal Peace in Afghanistan. Much of the statebuilding effort has been conceived as a warfighting tactic by the U.S.-led coalition, most explicitly in the counterinsurgency strategy pursued by General Petraeus and General McChrystal, which combined a surge in troop numbers with a greater emphasis on 'population 
security' and 'winning hearts and minds'. Impunity for human rights violations, corruption and other abuses facilitated the co-option and subversion of statebuilding by the War in Terror in less conspicuous ways, which have to do with its role in the growth of a predatory political economy dominated by illicit networks and fueled by an influx of money. In some cases, rampant impunity undermined the statebuilding project in ways that have complicated the war effort and destabilized the war coalition. This underscores once again the complex role of impunity in the reproduction of the War on Terror culture, serving both as an enabling and a constraining factor for the pursuit of specific objectives and practices and thereby shaping their continuous refinement and realignment.

The process of co-option of statebuilding can be traced in the security sector, for example through the progressive militarization of policing and deployment of newly created police forces in combat roles. Impunity serves an important function in that process. It ensures that abuses in the security structures do not prevent the implicated commanders and forces from continuing to enjoy international support (political and financial) and to act as vehicles for capturing and redirecting resources towards the War on Terror. Consider the case of Abdul Raziq, a local strongman-turned-police chief in Kandahar province. He began his career as a militia commander in charge of the border police in Spin Boldak, where he was implicated in human rights violations and the drugs trade. His rise to power is attributed to his reputation as an effective fighter against the Taliban and his links to U.S. forces and the Karzai family. As a police chief in Kandahar, Raziq controlled both the Afghan National Police (ANP) and the Afghan Local Police (ALP), an initiative to create or formally enlist local armed groups in the fight against the Taliban. Forces under Raziq's command are responsible for well-documented and 
publicized cases of torture, enforced disappearances and extrajudicial executions (Human Rights Watch 2015: 71-82). Despite significant publicity and pressure to remove him, Raziq was able to maintain his position and senior U.S. officials continued to praise his successes on the battlefield.

By helping to co-opt and subvert peacebuilding and statebuilding, rampant impunity can be useful in the War on Terror but it can also become a constraint. A central aim of Liberal Peace interventions is to help the state regain its monopoly on violence - an objective shared by many proponents of the War on Terror, who view weak and failed states as incubators for violent extremism and terrorist activity. And yet, in Afghanistan subverting the statebuilding project has contributed to a progressive deterioration of security and an increasingly fragmented security landscape. The inability of the Afghan state to centralize the means of coercion and mobilize capital challenges its legitimacy, creating space for the insurgency to grow. Reluctant to acknowledge the deep tensions between the War on Terror and the Liberal Peace, international actors have tended to respond by scaling back statebuilding goals, settling for Afghan 'good-enough' governance and 'acceptable-levels of corruption'.

Over time, the political costs of accountability became too high: prosecuting the War on Terror depended on many of the same actors and networks responsible for driving state capture and generating serious crises. The case of Kabul Bank is instructive. Almost one billion U.S. dollars of bank assets were stolen by a corrupt network that spanned the political, economic, and criminal elite and was closely tied to the families of President Karzai and Vice President Fahim. Efforts to pursue a measure of accountability were repeatedly frustrated, revealing the extent to which illicit networks had infiltrated and captured the state. There wasn't enough 
leverage in the system to hold to account those most responsible for the collapse of Kabul Bank, even though the crisis threatened the financial viability of the state. One UN official we interviewed at the time argued that accountability was highly unlikely since neither Karzai nor the United States were prepared to risk losing the support of key powerbrokers: "It is not possible to run the war effort without paying the bad guys" (Author Interview, Kabul, July 2011).

\section{Conclusion}

Security cultures theory provides a novel analytical lens for explaining human rights outcomes in counterterrorism and peace operations, generating insights that have the potential to advance both human rights research and security studies. Approaching the War on Terror and the Liberal Peace as security cultures and drawing on empirical evidence from Afghanistan, this paper demonstrates how impunity works as a mechanism for reproduction and diffusion of the War on Terror and for co-option and subversion of the Liberal Peace. The argument is elaborated by examining the political functions of impunity but this mode of analysis could also be useful for investigating its economic functions.

The argument has theoretical and practical implications. The role of impunity in determining pathways in the security field might be greater than previously understood. Impunity can shape individual security cultures by serving both as an enabling and a constraining factor in their reproduction, thereby helping to explain how particular cultures might adapt and evolve over time. But impunity may also influence the interactions between security cultures and affect their outcomes in important ways, helping to account for the 
emergence of dominant cultures and their ability to capture capabilities and resources of other cultures.

As the first front in the War on Terror, Afghanistan became a testing ground for theories of statebuilding and peacebuilding, counterinsurgency and counterterrorism. Understanding how rampant impunity has affected this process of experimentation and adaptation helps to account for the overall trajectory of the War on Terror and the global security pathways it set into motion. Whereas our analysis of impunity emphasizes how the statebuilding project in Afghanistan was hijacked by the War on Terror, the dominant narrative about the experience in Afghanistan (and Iraq) tends to neglect the role of impunity and frames nation-building and statebuilding as discredited approaches. What remains of the War on Terror are the sort of tactics and methods that are most problematic from a human rights perspective - airstrikes, targeted assassinations, reliance on local proxies and strongmen - and most likely to encourage further violence, radicalization and escalation.

The contradictions generated by impunity, however, might open up space for alternative approaches. The human rights community has focused its efforts on curbing the worst practices of the War on Terror. While understandable and important, that approach has left largely intact the mechanisms through which such practices were justified and produced in the first place. The disruptive potential of tackling impunity head-on has been mostly untapped, as political opportunities for pursuing accountability opened up and closed without being fully exploited. This might explain why many of the gains made by the human rights community are so precarious and reversible, and why they have not been sufficient to influence the pathway of the fight against terrorism in decisive ways. As discussions of counterterrorism and human 
rights appear to be gaining momentum once again, it is critical for human rights advocates to assimilate these lessons from their own struggle since 9/11. In practical terms, that means a far greater emphasis on developing strategies for strengthening and activating existing accountability mechanisms - political and legal, domestic as well as international - and experimenting with new approaches and instruments for combating impunity.

Notes

' See, for example, the discussion in Clark 2013.

ii See the U.S. government documents obtained by the National Security Archive at George Washington University, available at https://nsarchive2.gwu.edu//NSAEBB/NSAEBB325/index.htm (accessed 15 January 2018). iii In December 2014 the U.S. Senate Select Committee on Intelligence declassified parts of its Study of the Central Intelligence Agency's Detention and Interrogation Program, which totals more than 6,700 pages. Only 525 pages of the Study were declassified, available at https://www.intelligence.senate.gov/study/2014/sscistudy1.pdf (accessed June 3, 2015). 
iv There is a substantial empirical literature that examines how abuse and predation by government- and U.S.-aligned actors has shaped the ability of the insurgency to recruit and gain traction in local communities. See, for example, Ladbury 2009; Carter and Clark 2010; Giustozzi 2012; Chayes 2015; Weigand 2017.

${ }^{\vee}$ Media reports suggest that the C.I.A. has expanded its covert operations in Afghanistan in recent years, deploying small teams of officers and contractors to hunt down Taliban fighters (Gibbons-Neff et al. 2017).

vi For an insightful analysis of the resulting tensions and contradictions from a gender perspective, see Wimpelmann 2017. 


\section{Bibliography}

Afghanistan Independent Human Rights Commission (2005) Peace, Reconciliation and Justice Action Plan of the Government of the Islamic Republic of Afghanistan, available at http://www.aihrc.org.af/media/files/Reports/Thematic\%20reports/Action_PIn_Gov_Af. pdf (accessed October 30, 2017).

Agamben, Giorgio (2005) State of Exception. Chicago and London: University of Chicago Press. Bartholomew, Amy (2006) 'Empire's Law and the Contradictory Politics of Human Rights'. In Amy Bartholomew (ed.) Empire's Law: The American Imperial Project and the 'War to Remake the World'. London: Pluto Press.

Bell, Christine (2008) On the Law of Peace: Peace Agreements and the Lex Pacificatoria. Oxford: Oxford University Press.

Bush, George W. (2001) 'Presidential Address to the United States of America', October 7, 2001, available at: http://www.whitehouse.gov/news/releases/2001/10/20011007-8.html (accessed 1 June 2017).

Butler, Judith (2004) Precarious Life: The Powers of Mourning and Violence. London: Verso. Carter, Stephen and Kate Clark (2010) No Shortcuts to Stability: Justice, Politics and Insurgency in Afghanistan. London: Chatham House.

Chamayou, Gregoire (2011) 'The Manhunt Doctrine'. Radical Philosophy 169, Sep/Oct 2011. Chandrasekaran, Rajiv (2012) Little America: The War within the War for Afghanistan. London: Bloomsbury.

Chinkin, Christine and Mary Kaldor (2017) International Law and New Wars. Cambridge: Cambridge University Press. 
Chinkin, Christine et al. (2016) 'Special Issue: Law, Justice and the Security Gap'. Journal of Conflict \& Security Law 21(1): 1-7.

Clark, Kate (2013) The Nerkh Killings: The Problem with 'Immunity' for US Soldiers. Kabul: Afghanistan Analyst Network.

Coburn, Noah (2018) Under Contract: The Invisible Workers of America's Global War. Stanford: Stanford University Press.

Ericson, Richard (2007) Crime in an Insecure World. Cambridge: Polity.

Felbab-Brown, Vanda (2016): 'Hurray for Militias? Not So Fast: Lessons from the Afghan Local Police Experience.' Small Wars \& Insurgencies 27(2): 258-281.

Felbab-Brown, Vanda (2017) ‘Afghanistan Affectations: How to Break Political-Criminal Alliances in Contexts of Transition'. United Nations University Centre for Policy Research, Series No. 8, April 2017.

Filkins, Dexter and Mark Mazzetti (2010) 'Karzai Aide in Corruption Inquiry Is Tied to C.I.A.' New York Times, August 25, 2010.

Forsberg, Carl (2010) Power and Politics in Kandahar. Washington, D.C.: Institute for the Study of War.

Foucault, Michel (1991) 'Governmentality'. In Peter Miller, Colin Gordon and Graham Burchell (eds) The Foucault Effect: Studies in Governmentality. Chicago: University of Chicago Press.

Galbraith, Jean (2003) 'The Bush Administration's Response to the International Criminal Court'. Berkeley Journal of International Law 21(3): 683-702.

Gearty, Conor (2006) Can Human Rights Survive? Cambridge: Cambridge University Press. 
Chayes, Sarah (2015) Thieves of State: Why Corruption Threatens Global Security. New York:

W.W. Norton.

Gibbons-Neff, Thomas, Eric Schmitt and Adam Goldman (2017) ‘A Newly Assertive C.I.A.

Expands Its Taliban Hunt in Afghanistan'. The New York Times, October 22.

Giustozzi, Antonio (2009) Empires of Mud: War and Warlords of Afghanistan. New York:

Columbia University Press.

Giustozzi, Antonio (2012) The Resilient Oligopoly: A Political-Economy of Northern Afghanistan 2001 and Onwards. Kabul: Afghanistan Research and Evaluation Unit.

Goodhand, Jonathan (2008) 'Corrupting or Consolidating the Peace? The Drugs Economy and Post Conflict Peacebuilding in Afghanistan'. International Peacekeeping 15(3): 405-423.

Gopal, Anand (2010) The Battle for Afghanistan: Militancy and Conflict in Kandahar. Report of the New America Foundation, November 2010.

Gray, Colin (1999) 'Strategic Culture as Context: The First Generation of Theory Strikes Back'. Review of International Studies 25(1): 49-69.

Grossman, Patricia (2009) Transitional Justice and DDR: The Case of Afghanistan. New York: International Center for Transitional Justice.

Herman, Edward and David Peterson (2010) The Politics of Genocide. New York: Monthly Review Press.

Human Rights Watch (2005) Blood Stained Hands: Past Atrocities in Kabul and Afghanistan's Legacy of Impunity. Kabul: Human Rights Watch.

Human Rights Watch (2015) Today We Shall All Die: Afghanistan's Strongmen and the Legacy of Impunity. Kabul: Human Rights Watch. 
Ignatieff, Michael (2004) The Lesser Evil: Political Ethics in an Age of Terror. Princeton:

Princeton University Press.

Kaldor, Mary (2016) 'Global Security Cultures: A Theoretical Framework for Analysing Security in Transition'. Security in Transition Working Paper, SiT/WP/06/16. London: London School of Economics and Political Science.

Kaldor, Mary (2018) Global Security Cultures. Cambridge: Polity.

Keen, David (2006) Endless War? Hidden Functions of the War on Terror. London: Pluto Press. Ladbury, Sarah and Cooperation for Peace and Unity (CPAU) (2009) Testing Hypotheses on Radicalization in Afghanistan: Why Do Men Join the Taliban and Hizb-i Islami?. Kabul: Department for International Development.

Maass, Citha (2011) 'Afghanistan's Drug Career: From War to Drug Economy'. Afghanistan Analysts Network Thematic Report 02/2011. Kabul and Berlin: Afghanistan Analysts Network.

Mashal, Mujib and Najib Rahim (2017). 'Afghan President Fires a Powerful Governor from Post He Held 13 Years.' The New York Times, December 18, 2017.

McCoy, Alfred (2012) Torture and Impunity: The U.S. Doctrine of Coercive Interrogation. Madison: The University of Wisconsin Press.

Mukhopadhyay, Dipali (2014) Warlords, Strongmen Governors, and the State in Afghanistan. New York: Cambridge University Press.

Newburn, Tim (2007) 'Governing Security: The Rise of the Privatised Military'. In David Downes et al. (eds) Crime, Social Control and Human Rights: From Moral Panics to States of Denial. Cullompton: Willan Publishing. 
Rangelov, Iavor (2016) 'Justice as a Security Strategy? International Justice and the Liberal Peace in the Balkans'. Journal of Conflict \& Security Law 21(1): 9-28.

Rangelov, lavor and Marika Theros (2012) 'Abuse of Power and Conflict Persistence in Afghanistan'. Conflict, Security \& Development 12(3): 227-248.

Rashid, Ahmed (2009) Descent into Chaos: The United States and the Failure of Nation Building in Pakistan, Afghanistan, and Central Asia. New York: Penguin Books.

Rubin, Barnett (2003) 'Transitional Justice and Human Rights in Afghanistan'. International Affairs 79(3): 567-581.

Rubin, Barnet (2015) 'What I Saw in Afghanistan'. New Yorker, July 1, 2015.

Ruttig, Thomas (2013) Some Things Got Better - How Much Got Good? A Review of 12 Years of International Intervention in Afghanistan. Kabul: Afghanistan Analysts Network.

Savage, Charlie (2017) 'Trump Poised to Lift Ban on C.I.A. 'Black Sites'. New York Times, January 25, 2017.

Schmitt, Carl (1996) The Concept of the Political. Chicago: Chicago University Press.

Schmitt, Carl (1985) Political Theology: Four Chapters on the Concept of Sovereignty. Chicago: Chicago University Press.

SIGAR (2016) Corruption in Conflict: Lessons from the U.S. Experience in Afghanistan, Report of the Special Inspector General for Afghanistan Reconstruction, available at http://www.globalsecurity.org/military/library/report/sigar/sigar-16-58-II.pdf (accessed 11 February 2017).

Strick van Linschoten, Alex and Felix Kuehn (2012) An Enemy We Created: The Myth of the Taliban/Al-Qaeda Merger in Afghanistan, 1970-2010. London: Hurst. 
Tamanaha, Brian (2004) On the Rule of Law: History, Politics, Theory. Cambridge: Cambridge University Press.

Tierney, John (2010) Warlord, Inc.: Extortion and Corruption along the U.S. Supply Chain in Afghanistan. Report of the Majority Staff, Subcommittee on National Security and Foreign Affairs, Committee on Oversight and Government Report, U.S. House of Representatives, Washington, DC.

UN Economic and Social Council (2005) Report of the Independent Expert to Update the Set of Principles to Combat Impunity, Diane Orentlicher. Addendum: Updated Set of Principles for the Protection and Promotion of Human Rights through Action to Combat Impunity. UN Doc. E/CN.4/2005/102/Add.1, February 8, 2005.

UN Security Council (2001) Agreement on the Provisional Arrangements in Afghanistan Pending the Re-Establishment of Permanent Government Institutions. UN Doc. S/2001/1154, December 5, 2001.

Watkin, Kenneth (2005) 'Humans in the Cross-Hairs: Targeting, Assassination and ExtraJudicial Killing in Contemporary Armed Conflict'. In David Wippman and Matthew Evangelista (eds) New Wars, New Laws? Applying the Laws of War to $21^{\text {st }}$ Century Conflicts. Ardsley: Transactional Publishers.

Weigand, Florian (2017) 'Afghanistan's Taliban - Legitimate Jihadists or Coercive Extremists?' Journal of Intervention and Statebuilding 11(3): 359-381.

Welch, Michael (2009) Crimes of Power \& States of Impunity: The U.S. Response to Terror. New Brunswick and London: Rutgers University Press.

Wilson, Richard Ashby (2005) 'Human Rights in the 'War on Terror". In Richard Ashby Wilson 
(ed.) Human Rights in the 'War on Terror'. New York: Cambridge University Press.

Wimpelmann, Torunn (2017) The Pitfalls of Protection: Gender, Violence, and Power in Afghanistan. Oakland: University of California Press.

Woodward, Bob (2002) Bush at War. New York: Simon and Schuster.

Zyck, Steven (2012) 'How to Lose Allies and Finance Your Enemy: The Economisation of Conflict Termination in Afghanistan'. Conflict, Security \& Development 12(3): 249-271. 